\title{
17 $\alpha$-METHYLTESTOSTERONE (ANABOLIC ANDROGENIC STEROIDS) ALTERS ACETYLCHOLINESTERASE ENZYME ACTIVITY IN DIFFERENT PARTS OF THE BRAIN IN FEMALE MICE, MUS MUSCULUS
}

\author{
SACHIN B PATIL, LAXMI S INAMDAR* \\ Department of Zoology, Molecular Endocrinology, Reproduction and Development Laboratory, Karnatak University, Dharwad - 580 003, \\ Karnataka, India. E-mail: Is_doddamani@yahoo.com
}

Received: 26 December 2017, Revised and Accepted: 16 February 2018

\section{ABSTRACT}

Aim: Anabolic androgenic steroids (AAS) are synthetic derivatives of the male sex hormone testosterone. Androgens and anabolic steroids have been used for therapeutic purpose with few exceptions. However, the abuse of AAS is a remarkably prevalent problem, particularly among athletes and adolescents. Supraphysiological doses of AAS exert profound effects on mental state and behaviors such as depression, anxiety, aggressiveness, and cognitive deterioration.

Objective: In the present investigation, we studied the impact of one of the AAS compounds, i.e., $17 \alpha$-methyltestosterone on acetylcholinesterase (AChE) enzyme activity in different brain parts of mice, namely, forebrain, hippocampus, midbrain, and hindbrain.

Methods: The adult female mice were assigned to four experimental groups to which different doses of $17 \alpha-\mathrm{MT}(0.5,5.0 \mathrm{and} 7.5 \mathrm{mg} / \mathrm{kg} \mathrm{bwt}$, respectively) were administrated s.c. for 30 days. A significant increase in AChE activity in forebrain and midbrain (low and medium dose treatment) suggests a reduction of cholinergic neurotransmission efficiency due to decrease in acetylcholine levels in trans-synaptic cleft. Further, concurrent reduction in AChE activity was observed in whole brain, hippocampus, and hindbrain of $17 \alpha$-MT-treated mice suggests the impairment in neuronal transmission. Since the regulation of cholinergic system through acetylcholine hydrolysis has been largely attributed to AChE activity, a significant reduction in its activity may lead to stress-related anxiety, memory loss with some cognitive and behavioral aspects in the mice.

Conclusion: Based on the observed results, we propose that $17 \alpha-\mathrm{MT}$, an alkylated steroid compound, has a negative impact on AChE enzyme activity in different parts of mice brain, leading to impairment in neuronal transmission.

Keywords: Anabolic-androgenic steroids, Acetylcholinesterase, Forebrain, Hippocampus, Midbrain, Hindbrain

(c) 2018 The Authors. Published by Innovare Academic Sciences Pvt Ltd. This is an open access article under the CC BY license (http://creativecommons. org/licenses/by/4. 0/) DOI: http://dx.doi.org/10.22159/ajpcr.2018.v11i5.24736

\section{INTRODUCTION}

Anabolic androgenic steroids (AAS) are, more often than not, widely abused by professional athletes, bodybuilders, and non-athletes to enhance athletic performance, muscle mass, promote self-confidence, and relieve fatigue. Indeed, AAS was originally designed for the clinical purpose for the treatment of endometriosis, aplastic anemia, male hypogonadism, and inoperable breast cancer [1,2]. However, doping with these AAS results in a broad spectrum of secondary adverse effects such as metabolic suppression, especially lipoprotein metabolism, hepatotoxic effects, antagonism of glucocorticoid carbolic effects, impairment in cardiovascular system, gonadal dysfunction, gynecomastia, and behavioral and psychiatric side effects [2-5]. Further, of late, the use of AAS is becoming increasingly widespread among the adolescent girls and woman athletes, to improve their muscle mass, physique, appearance, and euphoria [6-9]. The actual influence of these compounds on overall physiology, central nervous system (CNS), and neurological alteration is yet to be established clearly.

A previous study from our laboratory reported that administration of a AAS compound Stanozolol leads to acceleration of granulopoiesis and stimulates an immune response (at physiological level only), though it alters the lipoprotein profile in mice [10]. Steroid hormones modulate memory processes through altering the functionality of several neurotransmitters such as acetylcholine by regulating acetylcholine transferase and acetylcholinesterase activities [11]. Cholinergic neurotransmission in the mammalian CNS is regulated predominantly by the enzyme acetylcholinesterase (AChE, EC 3.1.1.7).
$\mathrm{AChE}$ is one of the efficient primary cholinesterases which terminates acetylcholine-mediated neurotransmission, by rapidly hydrolyzing acetylcholine $(\mathrm{ACh})$ into acetate and choline $[12,13]$. Further, ACh is the major neurotransmitter involved in cortical activation, attention, memory, learning, pain, control of motor tone, locomotion, and control of autonomic functions [14].

It is known that androgen receptors are present in most of the body parts including CNS and influence many neuronal functions through both classical genomic effects and also rapid membrane effects. Sustained use of AAS has an impact on those areas of the CNS that are involved in emotional and cognitive responses such as sexuality, anxiety, aggression, memory, and development of drug dependence [15-19]. The androgen $17 \alpha$-methyltestosterone $(17 \alpha-$ MT), an alkylated steroid compound at $17 \alpha$ position of steroid nucleus and the most frequently abused AAS compound, has been selected for the present study to investigate its impact on different areas of the brain which are associated with wide range of functions including emotional and cognitive regulation.

\section{METHODS}

21/2-month-old female mice exhibiting normal estrous cycle (25-30 g) were obtained from the mice colony, maintained in the Department of Zoology, Karnatak University, Dharwad. They were housed in individual cages at room temperature $\left(27 \pm 1^{\circ} \mathrm{C}\right)$ with natural-cum-artificial light for 12-14 $\mathrm{h}$ and fed with a pelleted diet (Gold Mohur, Lipton, India) and water ad libitum. 


\section{Hormone treatment}

$17 \alpha$-MT was obtained from Sigma-Aldrich Chemical Co., USA. The mice were weighed and allocated to four experimental groups comprising five animals in each $(n=5)$. Doses of $17 \alpha$-MT administrated in the experiment were so chosen as to stimulate the range of doses taken by human female users [20]. The first experimental group that received $1 \%$ of alcohol acted as a baseline (control). The $2^{\text {nd }}, 3^{\text {rd }}$, and $4^{\text {th }}$ group received $17 \alpha$-MT daily, for 30 days, by s.c. injection in $1 \%$, respectively (LD - low dose-0.5; medium dose (MD) -5.0; and High dose (HD) $-7.5 \mathrm{mg} / \mathrm{kg}$ bwt). On the $31^{\text {st }}$ day, the mice were sacrificed by the inhalation of diethyl ether.

\section{Separation of different parts of brain}

After scarifying the animal, brain was extracted out from the skull and rinsed in cold phosphate-buffered saline to remove the excess blood. Before the separation of brain parts, it was kept on the cold metal plate placed on the crushed ice in a tray. After confirming its hardness precisely separated the different brain parts, namely, forebrain, midbrain, hindbrain, and hippocampus regions. Each brain part was homogenized and stored at $-80^{\circ} \mathrm{C}$ until assay.

\section{Quantification of AChE enzyme activity}

Fresh brain from the treated as well as the control mice, immediately after autopsy, were homogenized in phosphate buffer ( $\mathrm{pH} 7.6)$ and centrifuged for $10 \mathrm{~min}$ at $8000 \mathrm{rpm}$. The supernatant was used as the source of the AChE activity. The enzyme activity was estimated as per the procedure described elsewhere $[21,22]$. The incubation mixture comprised of $0.2 \mathrm{ml}$ of $20 \mathrm{mM}$ phosphate buffer ( $\mathrm{pH} 7.6$ ), $0.1 \mathrm{ml}$ of $8 \mathrm{mM}$ acetylcholine iodide, and $40 \mu \mathrm{l}$ of tissue supernatant. The incubation was carried out at room temperature for $30 \mathrm{~min}$. The reaction was terminated by adding $1.8 \mathrm{ml}$ of (5,5-Dithiobis(2-nitrobenzoic acid). The absorbance was measured immediately at $412 \mathrm{~nm}$ using ultraviolet -VISIBLE spectrophotometer (Hitachi, U-2800).

\section{Statistical analysis}

Data were expressed as a mean \pm standrad error comparison of normally distributed variables across groups were made using one-way analysis of variance followed by Tukey's post hoc test. The level of statistical significance was set at $\mathrm{p}<0.01$. Data were analyzed using SPSS (version 16.0) and the recorded values are summarized in figures.

\section{RESULTS}

The observed results are depicted in Figs. 1 and 2. The whole brain homogenates of all the $17 \alpha$-MT treateted mice revealed a significant depletion in AChE activity $\left(F_{3.16}=6.80, P<0.05\right.$; Fig. 1a) as compared with control. As shown in Fig. 1b, the activity levels of AChE in forebrain region were found to be elevated significantly $\left(F_{3,16}=138.48, \mathrm{p}<0.01\right)$. In contrast, a significant depletion in AChE activity was observed in hippocampus $\left(F_{3,16}=128.16, \mathrm{p}<0.01\right.$; Fig. $\left.1 \mathrm{c}\right)$ as well as in hindbrain regions $\left(F_{3,16}=185.8, \mathrm{p}<0.01\right.$; Fig. $\left.2 \mathrm{~b}\right)$ in the entire treatment group as compared to control. In case of midbrain, an increased AChE activity in LD and MD treatment groups and drastic reduction in $\mathrm{HD}(\mathrm{p}<0.01)-$ treated mice was noticed when compared to control (Fig. 2a).

\section{DISCUSSION}

Steroid hormones are known to affect neurotransmission through direct effects on the cellular membrane, modulation of the synthesis, and degradation of neurotransmitters by altering their metabolism [11]. ACh is an essential player in the formation, maintenance, and evocation of memory processes. In the present investigation, we evaluated the impact of one of the AAS compounds $17 \alpha$-MT on the AChE enzyme activity in different brain regions. A significant increase in AChE activity in forebrain and midbrain (low and medium dose treatment) suggests a reduction of cholinergic neurotransmission efficiency due to a decrease in acetylcholine levels in the synaptic cleft which may be related to neurotoxicity and neuronal degeneration [23]. Parallel to this, subchronic treatment of nandrolone decanoate (ND) resulted in the augmented levels of

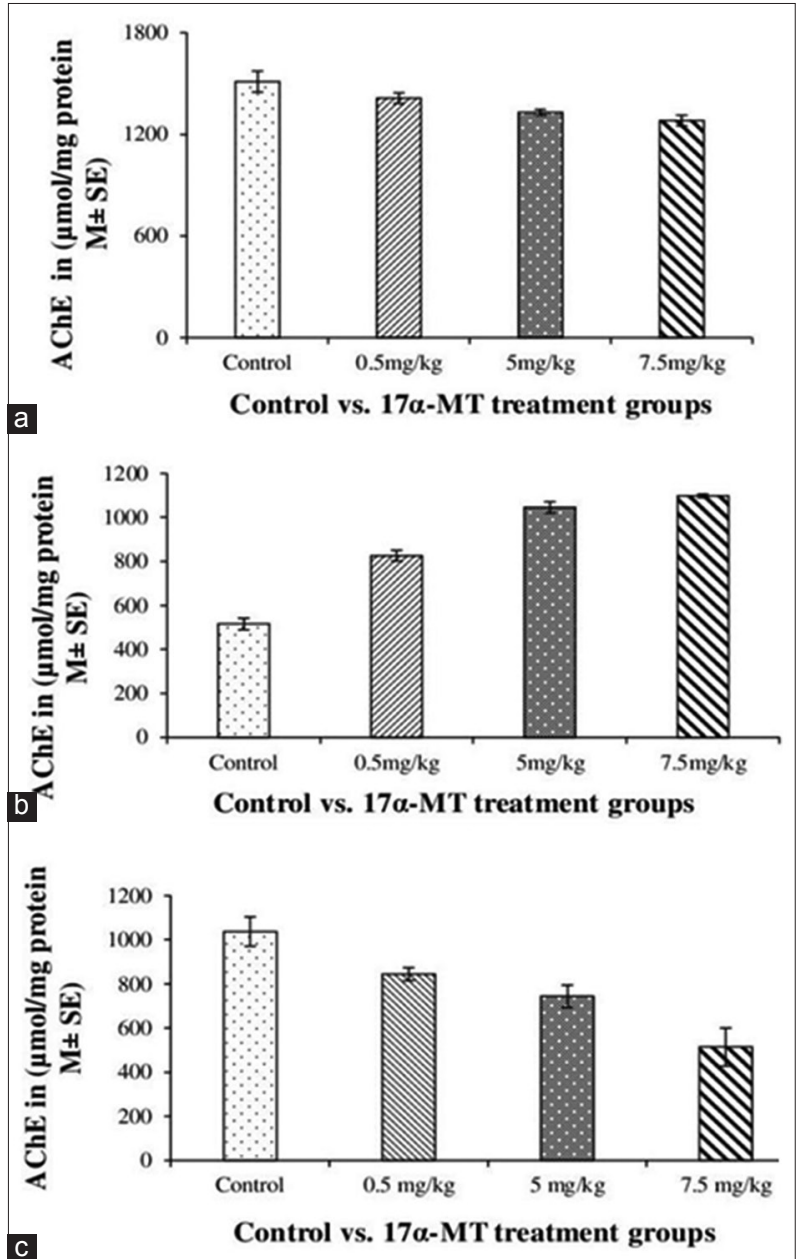

Fig. 1: (a) Acetylcholinesterase enzyme activity in whole brain (b) forebrain, and (c) hippocampus in control and 17 $\alpha$-MT treatment mice. Data are represented as a mean \pm standard error which is analyzed by one-way analysis of variance followed by Tukey's post hoc test $(\mathrm{p}<0.01)$

AChE activity in cerebellum and striatum of rat brain affecting the cholinergic system and consequently the CNS [24]. Likewise, ND treatment induced behavioral changes including oxidative damage, inflammation, and imbalance in brain neurotransmitter systems, modulation of nerve growth factor, and neuronal apoptosis [25-27]. Furthermore, some studies have demonstrated that the prolonged overexpression of AChE activity in the CNS implies cognitive and neuroanatomic pathologies/disorders $[28,29]$.

Further, in the present investigation, concurrent reduction in AChE activity was observed in hippocampus, hindbrain as well as whole brain of $17 \alpha$-MT treateted mice as compared to control suggests the accumulation of $\mathrm{ACh}$ at synaptic junctions which in turn would result in the impairment of neuronal transmission. Based on the observed results, we propose that the inhibitory effect of $17 \alpha$-MT may dependent on its binding capacity to the AChE enzyme activity site. A previous study from our laboratory reported that Stanozolol, a potent AAS compound, induced alteration in local antioxidant cascade besides altering AChE activity in brain and kidney in female mice [30]. Since the regulation of cholinergic system through acetylcholine hydrolysis has been largely attributed to AChE activity, a significant reduction in its activity may lead to stress-related anxiety and memory loss, thus interfering with some cognitive and behavioral aspects in the mice. An excess level of ACh was shown to be neurotoxic, while the opposite is also true since low levels of ACh in the synaptic junction may influence memory negatively $[31,32]$. Reduction in AChE activity 


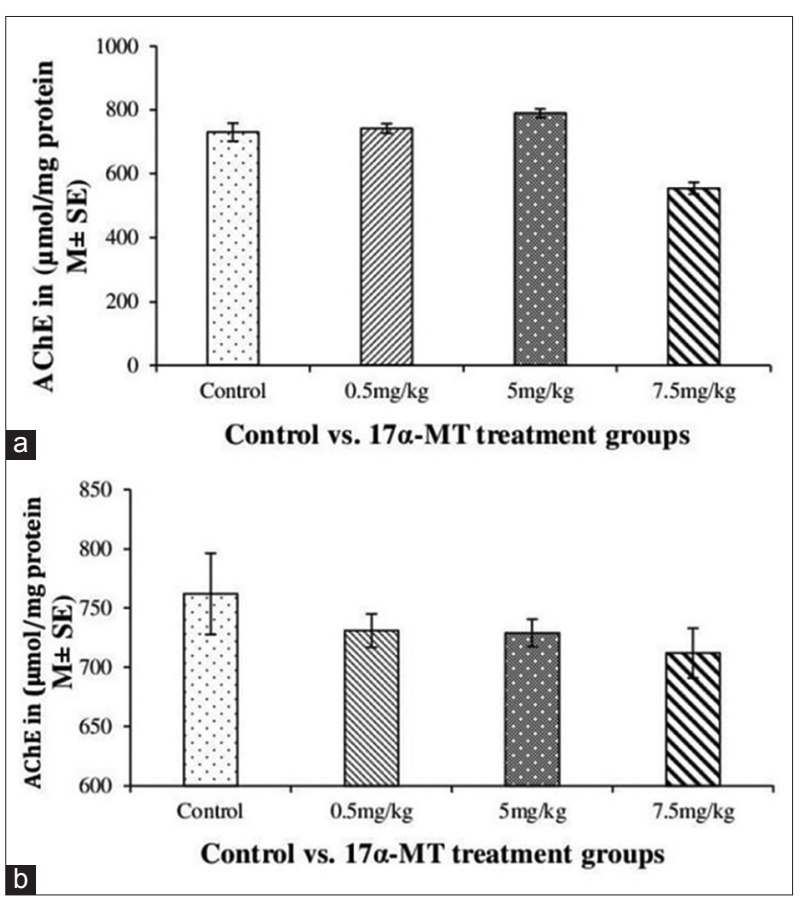

Fig. 2: (a) Acetylcholinesterase enzyme activity in midbrain and

(b) hindbrain in control and $17 \alpha$-MT treatment groups. Data were represented as a mean \pm standard error and were analyzed by one-way analysis of variance followed by Tukey's post hoc test $(p<0.01)$.

in hippocampus promotes behavior-related anxiety and depression as suggested by Mineur et al. [33]. A report on human imaging study suggests the elevation of acetylcholine (ACh) levels in patients who are actively depressed, as measured by occupancy of nicotinic receptors throughout the brain and remain high in patients who have a history of depression [34]. In contrast, increased AChE activity in the cerebral and hippocampus was found in the boldenone treated rats [35]. Likewise, increase in AChE activity following treatment of ND suggested impairment in neurotransmission and cholinergic modulation [24]. Generally, maintenance of ACh levels is necessary for normal memory function, but excessive AChE activity leads to disruption of ACh in hippocampal cholinergic synapses [36]. There are also reports that show that the ingestion of AAS affects neuronal activity in the hypothalamus and forebrain [37] by promoting neurodegenerative apoptotic effect [38]. Likewise, the supraphysiological levels of testosterone initiate apoptotic cascade in neuronal cells of human neuroblastoma cell lines [39].

Based on results of the present study, the following inferences are drawn:

1. Increase in $\mathrm{AChE}$ enzyme activity in forebrain and midbrain indicates a reduction in cholinergic neurotransmission efficiency due to a decrease in acetylcholine levels in the trans-synaptic cleft.

2. Decreased activity of AChE in hippocampus, hindbrain, as well as whole brain suggest impairment in neuronal transmission, in turn may lead to anxiety and depression in mice.

\section{ACKNOWLEDGMENTS}

This work has been carried out with financial support from the UGC under CPEPA. One of the authors (SBP) is thankful to the UGC-CPEPA for a fellowship. Partial financial support from UGC under SAP-DSA-I is gratefully acknowledged.

\section{CONFLICTS OF INTEREST}

Authors have none to declare.

\section{REFERENCES}

1. Kochakian CD. Anabolic androgenic steroid: A historical perspective and definitions. In: Yesalis CE, editor. Anabolic Steroids in Sports and Exercise. Champaign, IL: Human Kinetics Publishers, Inc; 1993. p. 3-33.

2. Basaria S, Wahlstrom JT, Dobs AS. Clinical review 130: Anabolic androgenic steroid therapy in the treatment of chronic diseases. J Clin Endocrinol Metab 2001;86:5108-17.

3. Shahidi NT. A review of the chemistry, biological action and clinical applications of anabolic- androgenic steroid. Clin Ther 2001;23:1355-90.

4. Kicman AT. Pharmacology of anabolic steroids. Br J Pharmacol 2008; 154:502-21.

5. Nieschlag E, Vorona E. Mechanisms in endocrinology Medical consequences of doping with anabolic androgenic steroids: Effects on reproductive functions. Eur J Endocrinol 2015;173:47-8.

6. Hartgens F, Kuipers H. Effects of androgenic-anabolic steroids in athletes. Sports Med 2004;34:513-54

7. NIDA. Research Report-Steroid Abuse and Addiction: NIH Publication No. 00-3721. Bethesda, MD: National Institute on Drug Abuse (NIDA); 2000.

8. Iriart JA, Andrade TM. Body-building, steroid use, and risk perception among young body-builders from a low-income neighborhood in the city of Salvador, Bahia State, Brazil. Cad Saude Publ 2002;18:1379-87.

9. Johnston LD, O'Malley PM, Bachman JG, Schulenberg JE. Monitoring the future national survey results on drug use, 1975-2012. Secondary School Students. Vol. I. Ann Arbor: Institute for Social Research, the University of Michigan; 2013. p. 604.

10. Inamdar Doddamani LS, Jayamma Y. Acceleration of neutrophil precursors' maturation and immunostimulation of $\mathrm{CD} 3+, \mathrm{CD} 4+$ lymphocytes by stanozolol in mice. J Steroid Biochem Mol Biol 2012;129:172-8

11. McEwen BS, Biegon A, Davis PG, Krey LC, Luine VN, McGinnis MY, et al. Steroid hormones: Humoral signals which alter brain cell properties and functions. Rec Prog Horm Res 1982;38:41-2.

12. Giacobini E, Pepeu G, editors. The Brain Cholinergic System in Health and Disease. Abingdon [England]: Informa Healthcare; 2006.

13. Silver A. The biology of Cholinesterases. The Netherlands: NorthHolland; 1974

14. Herlenius E, Lagercrantz H. Development of neurotransmitter systems during critical periods. Exp Neurol 2004;190:8-21.

15. Thiblin I, Kristiansson M, Rajs J. Anabolic androgenic steroids and behavioural patterns among violent offenders. J Forensic Psychiatry 1997:8:299-10.

16. Hall RC, Hall RC, Chapman MJ. Psychiatric complications of anabolic steroid abuse. Psychosomatics 2005;46:285-90.

17. Papazisis G, Kouvelas D, Mastrogianni A, Karastergiou A. Anabolic androgenic steroid abuse and mood disorder: A case report. Int J Neuropsychopharmacol 2007;10:291-3.

18. Trenton AJ, Currier GW. Behavioural manifestations of anabolic steroid use. CNS Drugs 2005;19:571-95.

19. Kaufman MJ, Janes AC, Hudson JI, Brennan BP, Kanayama G, Kerrigan AR, et al. Brain and cognition abnormalities in long-term anabolic-androgenic steroid users. Drug Alcohol Depend 2015;152:47-6.

20. Strauss RH, Yesalis CE. Additional effects of anabolic steroids on women. In: Yesalis CE, editor. Anabolic Steroids in Sports and Exercise. Champaign, IL: Human Kinetics Publishers Inc.; 1993. p. 151-60.

21. Ellman GL, Courtney KD, Andres V Jr, Featherstone RM. A new and rapid colorimetric determination of acetyl cholinesterase activity. Biochem Pharmacol 1961;7:88-95.

22. Gorun V, Proinov I, Baltescu V, Balaban G, Barzu O. Modified Ellman procedure for assay of cholinesterases in crude enzymatic preparations. Anal Biochem 1978;8:324-6.

23. Jameson RR, Seidler FJ, Slotkin TA. Nonenzymatic functions of acetylcholinesterase splice variants in the developmental neurotoxicity of organophosphates: Chlorpyrifos, chlorpyrifos oxon, and diazinon. Environ Health Perspect 2007;115:65-70.

24. Martins DB, Mazzanti CM, Spanevello R, Schmatz R, Cargnelutti JF, Schmidt C, et al. Subchronic administration of nandrolone decanoate in acetylcholinesterase activity in wistar rats. Comp Clin Pathol 2012;21:256-68.

25. Pieretti S, Mastriota M, Tucci P, Battaglia G, Trabace L, Nicoletti F, et al. Brain nerve growth factor unbalance induced by anabolic androgenic steroids in rats. Med Sci Sports Exe 2013;45:29-5

26. Tanehkar F, Rashidy-Pour A, Vafaei AA, Sameni HR, Haghigh S, Miladi-Gorji $\mathrm{H}$, et al. Voluntary exercise does not ameliorate spatial 
learning and memory deficits induced by chronic administration of nandrolone decanoate in rats. Horm Behav 2013;63:158-65.

27. Rainer Q, Speziali S, Rubino T, Dominguez-Lopez S, Bambico FR, Gobbi $\mathrm{G}$, et al. Chronic nandrolone decanoate exposure during adolescence affects emotional behavior and monoaminergic neurotransmission in adulthood. Neuropharmacology 2014;83:79-8.

28. Kaufer D, Friedman A, Seidman S, Soreq H. Acute stress facilitates longlasting changes in cholinergic gene expression. Nature 1998;393:373-7.

29. Singh A, Jatav VK, Sharma S. Virtual screening and admet analysis for identification of inhibitors against acetylcholin esterase associated with Alzheimer's disease. Int J Pharm Pharm Sci 2014;6:155-9.

30. Patil SB, Inamdar Doddamani LS. Stanozolol induces alterations in antioxidant cascade and AChE activity in brain and renal function in female mice, Mus musculus. Am J Pharm Health Res 2017;5:89-904.

31. Soreq H, Seidman S. Acetylcholinesterase-new roles for an old actor. Nat Rev Neurosci 2001;2:294-302.

32. Tougu V, Kesvatera T. Role of ionic interactions in cholinesterase catalysis. Biochim Biophys Acta 1996;1298:12-30

33. Mineur YS, Obayemi A, Wigestrand MB, Fote GM, Calarco CA, Li $\mathrm{AM}$, et al. Cholinergic signaling in the hippocampus regulates social stress resilience and anxiety- and depression-like behavior. PNAS
2013;110:3573-8

34. Saricicek A, Esterlis I, Maloney KH, Mineur YS, Ruf BM, Muralidharan A, et al. MRCPsych. Persistent $\beta 2 *$-nicotinic acetylcholinergic receptor dysfunction in major depressive disorder. Am J Psychiatry 2012;169:851-9.

35. Bueno A, Carvalho FB, Gutierres JM, Lhamas C, Andrad CM. A comparative study of the effect of the dose and exposure duration of anabolic androgenic steroids on behavior, cholinergic regulation, and oxidative stress in rats. PLoS One 2017;12:e0177623.

36. Abreu-Villaca Y, Filgueiras CC, Manhaes AC. Developmental aspects of the cholinergic system. Behav Brain Res 2011;221:367-78.

37. Oberlander JG, Poeter DM, Penatti CA, Henderson LP. Anabolic androgenic steroid abuse: Multiple regulation GABAergic synapses in neuroendocrine control regions of rodent forebrain. J Neuroendocrinol 2012;24:202-14

38. Tugyan K, Ozbal S, Cliaker S, Kiray M, Pekcetin C, Ergur BU, et al. Neuroprotective effect of erythropoietin on nandrolone decanote induced brain injury in rats. Neurosci Lett 2013;533:28-33.

39. Estrada M, Varshney A, Ehrlich BE. Elevated testosterone induces apoptosis in neuronal cells. J Biol Chem 2006;281:25492-501. 